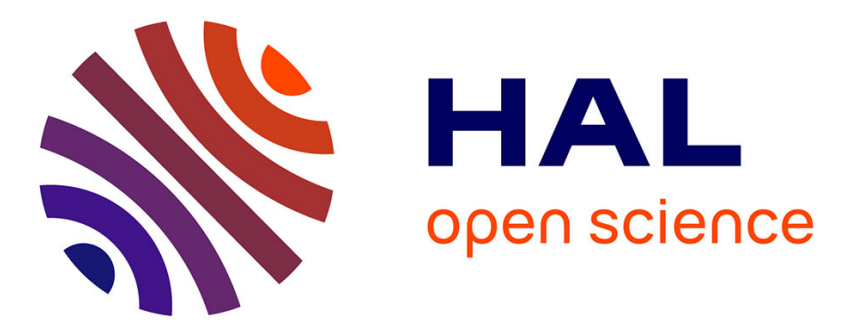

\title{
Robust correlates of county-level growth in the United States
}

\author{
Matthew J Higgins, Andrew T Young, Daniel Levy
}

\section{To cite this version:}

Matthew J Higgins, Andrew T Young, Daniel Levy. Robust correlates of county-level growth in the United States. Applied Economics Letters, 2008, 17 (3), pp.293-296. 10.1080/13504850701720254 . hal-02387733

\section{HAL Id: hal-02387733 \\ https://hal.science/hal-02387733}

Submitted on 30 Nov 2019

HAL is a multi-disciplinary open access archive for the deposit and dissemination of scientific research documents, whether they are published or not. The documents may come from teaching and research institutions in France or abroad, or from public or private research centers.
L'archive ouverte pluridisciplinaire HAL, est destinée au dépôt et à la diffusion de documents scientifiques de niveau recherche, publiés ou non, émanant des établissements d'enseignement et de recherche français ou étrangers, des laboratoires publics ou privés. 


\title{
Robust Correlates of County-Level Growth in the U.S.
}

\author{
Matthew J. Higgins \\ College of Management \\ Georgia Institute of Technology \\ Atlanta, GA 30308-0520 \\ mhiggins@mgt.gatech.edu
}

Tel: 404-894-4368. Fax: 404-894-6030

Andrew T. Young*

Department of Economics

University of Mississippi

University, MS 38677

atyoung@olemiss.edu

Tel: 662-915-5829, Fax: 404-894-6030

\author{
Daniel Levy \\ Department of Economics \\ Bar-Ilan University \\ Ramat-Gan 52900, Israel \\ levyda@mail.biu.ac.il
}

Tel: +972-3-531-8331, Fax: +972-3-535-3180

JEL Codes: O40, O11, O18, O51, R11, H50, and H70

Key Words: Economic Growth, Conditional Convergence, Extreme Bounds Analysis, County-Level Data

Last Revision: May $4^{\text {th }}, 2007$

\footnotetext{
* Corresponding Author. We thank Jordan Rappaport for kindly sharing with us some of his data and computer codes and for providing helpful suggestions throughout the study. All errors are ours.
} 


\title{
Robust Correlates of County-Level Growth in the U.S.
}

\begin{abstract}
Higgins et al. (2006) report several statistically significant partial correlates with U.S. per capita income growth. However, Levine and Renelt (1992) demonstrate that such correlations are hardly ever robust to changing the combination of conditioning variables included. We ask whether the same is true for the variables identified as important by Higgins et al. Using the extreme bounds analysis of Levine and Renelt, we find that the majority of the partial correlations can be accepted as robust. The variables associated with those partial correlations stand solidly as variables of interest for future studies of U.S. growth.
\end{abstract}




\section{Introduction}

Higgins et al. (2006) study U.S. county-level income growth from 1970 to 1998 controlling for 41 demographic conditioning variables. Their findings include: (1) conditional $\beta$ convergence; (2) federal, state and local government employment negatively correlate with growth; (3) the relationship between educational attainment and growth is nonlinear; and (4) finance, insurance, and real estate industry employment and entertainment industry employment correlate positively with growth, whereas education employment correlates negatively with growth. Higgins, et al. use a consistent 3SLS estimation method of Evans (1997a, 1997b) and include all 41 conditioning variables in the cross-sectional regressions.

However, Levine and Renelt (1992), employing a version of Leamer's (1983, 1985) extreme bound analysis (EBA), show that growth regression estimates can be very sensitive to small changes in the set of conditioning variables. ${ }^{1}$ In order to determine whether findings (1)-(4) from Higgins et al. (2006) are model dependent, we replicate Levine and Renelt's EBA using the same data set as Higgins et al. We find that 7 out of 11 variables of interest are robust partial correlates with U.S. county-level growth.

Section 2 outlines the EBA methodology and describes the data. Section 3 reports our results. We conclude in Section 4.

\section{Extreme Bounds Analysis (EBA)}

In response to sensitivity issues, Leamer $(1983,1985)$ proposes an EBA to identify "robust" empirical relations. For a specific variable of interest, the extreme bounds of the

\footnotetext{
${ }^{1}$ Levine and Renelt (1992) find that, using an international sample, very few variables are robust correlates with growth. Sala-i-Martin, et al. (2004) introduce an alternative Bayesian sensitivity analysis. Their analysis is motivated by the belief that Levine and Renelt's "test is too strong for any variable to pass: any one regression model (no matter how well or poorly fitting) carries a veto" (p. 814). In contrast, we conclude that the majority of variables identified as important by Higgins et al. (2006) are not "vetoed" by the Levine and Renelt test.
} 
distribution of the associated coefficient estimates are calculated as the smallest and largest values that are not rejected at the 0.05 significance level given all possible combinations of the remaining conditioning variables taken 3 at a time. If the two bounds have differing signs, then the variable is labeled as fragile; otherwise it is labeled robust. ${ }^{2}$

The 11 conditioning variables of interest are listed in Table 1 . These variables are 1970 values for 3,058 U.S. counties. The dependent variable is per capita real income growth from 1970 to 1998 . See Higgins et al (2006, Table 1 and Section III) for a description of the data set, including the list of the remaining 30 conditioning variables.

Since it is well-established that initial income be included in growth regressions, the EBA for "income" is constituted by the results of $\mathrm{C}(40,3)=9,880$ OLS regressions. The EBAs for the remaining 10 conditioning variables of interest are constituted by the results of $C(39,3)=9,139$ OLS regressions.

\section{Results of Extreme Bounds Analysis}

The extreme bounds for coefficients are reported in Table 2 along with their 95 percent confidence intervals. A full 7 of 11 variables, found to be significant correlates with economic growth by Higgins et al. (2006), are robust as defined by the EBA. Furthermore, the robust correlates according to the EBA carry the same signs as reported in Higgins et al. (2006).

First, the initial level of income is a robust, negative correlate with per capita income growth. This confirms that a conditional convergence effect exists across the U.S. at the countylevel. This can also be viewed as consistent with studies by Barro and Sala-i-Martin (1992),

\footnotetext{
${ }^{2}$ Statistically insignificant coefficient estimates are discarded from the analysis; including them would make for an unreasonably demanding test. An insignificant coefficient estimate of a different sign than extreme bounds of like signs is, rather than a contradiction of those bounds, merely a tentative acceptance of the null of zero partial correlation.
} 
Evans and Karras (1996a, 1996b), Sala-i-Martin (1996), and Evans (1997a, 1997b) who document conditional convergence using state-level data; and with Young et al. (2006) who find conditional convergence within many individual U.S. states using county-level data. ${ }^{3}$ The existence of conditional convergence is always encouraging in the limited sense that it implies that if a relatively poor economy can emulate the policies and institutions of its wealthier counterparts, then it can expect to grow faster and catch-up in terms of its per capita income. The robust estimated effects of educational attainment variables appear reasonable. The larger a percent of a county's population not obtaining the remedial communication and analytical skills associated with completing high school, the lower is the county's growth rate. Likewise, a larger percent of a population achieving at least 4 college-years-worth of human capital correlates with a higher rate of growth. ${ }^{4}$ Of note, the effect associated with some college attainment, but less than a bachelor degree, is fragile. This can be viewed as consistent with Higgins et al.'s (2006) finding that no statistically significant effect is associated with that variable. One interpretation is that the opportunity costs of education at those levels of attainment are comparable to the social returns.

Turning to the government employment variables, the robust negative correlations associated with federal and local government are consistent with Higgins et al. (2006). However, Higgins et al. also found state government employment to be negatively correlated (significantly at the 1 percent level) with growth using 3SLS estimation. Here we find that, using an EBA, that negative correlation is fragile. Of note, Higgins et al. (2006) also report, as a baseline, OLS

\footnotetext{
${ }^{3}$ This type of convergence is known as $\beta$-convergence and is necessary but not sufficient for $\sigma$-convergence, i.e., for a narrowing of the income distribution over time. Young et al. (2007) find that, over the same 1970 to 1998 time period, statistically significant $\sigma$-divergence actually occurred.

${ }^{4}$ Our conditioning variables include a dummy variable that takes the value of 1 if the county includes a college or university with enrollment of 10,000 or more and accounts for at least 5 percent of the total population. In Higgins et al. (2006) the inclusion did not render the bachelor+ coefficient estimate insignificant.
} 
coefficient estimates. For the state employment variable the Higgins et al. OLS estimate is negative but insignificant; the EBA here produces a stronger finding that, changing the set of conditioning variables, can produce both negative and positive statistically significant coefficient estimates.

Two of the industry employment variables are robust, positive correlates with countylevel growth. In both cases the positive sign is consistent with the findings of Higgins et al. (2006). While growth effects associated with entertainment and recreational services are not widely documented in the literature, the robust positive correlation of growth with the prevalence of finance, insurance, and real estate industry is in agreement with existing cross-country evidence. $^{5}$

\section{Conclusions}

Higgins et al. (2006) report several statistically significant partial correlates with U.S. per capita income growth at the county-level. However, Levine and Renelt (1992) demonstrate that, for cross-country data sets, such correlations are hardly ever robust to changing the combination of conditioning variables included. It is natural, then, to ask whether the same is true for the variables identified as important by Higgins et al.

We carry out an extreme bounds analysis of the Levine and Renelt (1992) type using the U.S. county-level data of Higgins et al. (2006). We find that the majority of the partial correlations put to test (7 out of 11) can be accepted as robust correlates with U.S. county-level growth. The variables associated with those partial correlations stand solidly as variables of interest for other studies of U.S. growth.

\footnotetext{
${ }^{5}$ Levine (2005) provides an overview of the empirical findings, as well as the theoretical literature motivating the studies.
} 


\section{References}

Barro, R.J., Sala-i-Martin, X.X., 1992 Convergence. Journal of Political Economy 100, 223-251.

Evans, P, 1997. How fast do economies converge? Review of Economics and Statistics 36, 219-25.

Evans, P., 1997. Consistent estimation of growth regressions. Unpublished Manuscript, available at http://economics.sbs.ohiostate.edu/pevans/pevans.html.

Evans, P., Karras, G., 1996. Do economies converge? evidence from a panel of U.S. states. Review of Economics and Statistics 78, 384-388.

Evans, P, Karras, G, 1996. Convergence revisited. Journal of Monetary Economics 37, 249-265.

Higgins, M.J., Levy, D., Young, A.T., 2006. Growth and convergence across the U.S: evidence from county-level data. Review of Economics and Statistics 88, 671-681.

Leamer, E. 1983. Let's take the con out of econometrics. American Economic Review 73, 31-43.

Leamer, E., 1985. Sensitivity analysis would help. American Economic Review 75, 308-313.

Levine, R., Renelt, D., 1992. A sensitivity analysis of cross-country growth regressions. American Economic Review 82, 942-963.

Levine, R., 2005. Finance and growth: theory and evidence. in Handbook of Economic Growth, Aghion P., Durlaf, S. eds. Elsevier Science, Netherlands.

Sala-i-Martin, X., Doppelhofer, G., Miller, R., 2004. Determinants of long-term growth: a Bayesian averaging of classical estimates (BACE) approach. American Economic Review 94, 813-835.

Young, A.T., Higgins, M.J., and Levy D., 2006. Heterogeneous convergence. working paper.

Young, A.T., Higgins, M.J., and Levy, D., 2007. Sigma convergence versus beta convergence: evidence from US county-level data. Journal of Money, Credit and Banking forthcoming. 


\section{Tables}

Table 1

Extreme Bounds of Coefficients on Variables of Interest

\begin{tabular}{|c|c|c|}
\hline Variable & Upper Bound & Source \\
\hline Income & $\begin{array}{l}\text { Real per capita personal income (excluding transfer } \\
\text { payments) }\end{array}$ & U.S. BEA \\
\hline $\begin{array}{l}\text { Education: } \\
\text { 9-11 years }\end{array}$ & $\begin{array}{l}\text { Percentage of the population with } 11 \text { years of education or } \\
\text { less }\end{array}$ & Census \\
\hline $\begin{array}{l}\text { Education: } \\
\text { H.S. diploma }\end{array}$ & $\begin{array}{l}\text { Percentage of the population with a high school diploma } \\
\text { but no more education }\end{array}$ & Census \\
\hline $\begin{array}{l}\text { Education: } \\
\text { some college }\end{array}$ & $\begin{array}{l}\text { Percentage of the population with college education but not } \\
\text { having obtained a bachelor degree }\end{array}$ & Census \\
\hline $\begin{array}{l}\text { Education: } \\
\text { bachelor }+\end{array}$ & $\begin{array}{l}\text { Percentage of the population holding a bachelor or higher } \\
\text { level degree }\end{array}$ & Census \\
\hline $\begin{array}{l}\text { Federal government } \\
\text { employment }\end{array}$ & $\begin{array}{l}\text { Percentage of the population employed by the federal } \\
\text { government }\end{array}$ & BEA \\
\hline $\begin{array}{l}\text { State government } \\
\text { employment }\end{array}$ & $\begin{array}{l}\text { Percentage of the population employed by the state } \\
\text { government }\end{array}$ & BEA \\
\hline $\begin{array}{l}\text { Local government } \\
\text { employment }\end{array}$ & $\begin{array}{l}\text { Percentage of the population employed by the local } \\
\text { government }\end{array}$ & BEA \\
\hline $\begin{array}{l}\text { Entertainment and } \\
\text { recreational } \\
\text { services }\end{array}$ & $\begin{array}{l}\text { Percentage of the population employed in entertainment or } \\
\text { recreational services }\end{array}$ & Census \\
\hline $\begin{array}{l}\text { Finance, insurance, } \\
\text { and real estate }\end{array}$ & $\begin{array}{l}\text { Percentage of the population employed in finance, } \\
\text { insurance or real estate }\end{array}$ & Census \\
\hline $\begin{array}{l}\text { Educational } \\
\text { services }\end{array}$ & $\begin{array}{l}\text { Percentage of the population employed in educational } \\
\text { services }\end{array}$ & Census \\
\hline
\end{tabular}

BEA denotes the U.S. Bureau of Economic Analysis; Census denotes the U.S. Census Bureau. All variables are 1970 values for 3,058 U.S. counties. 


\section{Tables (cont.)}

Table 2

Results of Extreme Bounds Analysis

\begin{tabular}{|c|c|c|c|}
\hline Variable & Lower Bound & Upper Bound & Verdict \\
\hline Income & $\begin{array}{l}-0.0175 \\
(-0.0188,-0.0162)\end{array}$ & $\begin{array}{l}-0.0044 \\
(-0.0053,-0.0035)\end{array}$ & Robust (-) \\
\hline Education: 9-11 years & $\begin{array}{l}-0.0293 \\
(-0.0343,-0.0244)\end{array}$ & $\begin{array}{l}-0.0048 \\
(-0.0095,-0.0002)\end{array}$ & Robust (-) \\
\hline Education: H.S. diploma & $\begin{array}{l}-0.0206 \\
(-0.0249,-0.0163)\end{array}$ & $\begin{array}{l}0.0071 \\
(0.0030,0.0112)\end{array}$ & Fragile \\
\hline Education: some college & $\begin{array}{l}-0.0497 \\
(-0.0583,-0.0411)\end{array}$ & $\begin{array}{l}0.0376 \\
(0.0288,0.0464)\end{array}$ & Fragile \\
\hline Education: bachelor + & $\begin{array}{l}0.0225 \\
(0.0150,0.0299)\end{array}$ & $\begin{array}{l}0.1111 \\
(0.1019,0.1204)\end{array}$ & Robust (+) \\
\hline $\begin{array}{l}\text { Federal government } \\
\text { employment }\end{array}$ & $\begin{array}{l}-0.0212 \\
(-0.0268,-0.0156)\end{array}$ & $\begin{array}{l}-0.0054 \\
(-0.0108,-0.0001)\end{array}$ & Robust (-) \\
\hline $\begin{array}{l}\text { State government } \\
\text { employment }\end{array}$ & $\begin{array}{l}-0.0233 \\
(-0.0293,-0.0172)\end{array}$ & $\begin{array}{l}0.0212 \\
(0.0150,0.0273)\end{array}$ & Fragile \\
\hline $\begin{array}{l}\text { Local government } \\
\text { employment }\end{array}$ & $\begin{array}{l}-0.0682 \\
(-0.0763,-0.0600)\end{array}$ & $\begin{array}{l}-0.0236 \\
(-0.0315,-0.0156)\end{array}$ & Robust (-) \\
\hline $\begin{array}{l}\text { Entertainment and } \\
\text { recreational services }\end{array}$ & $\begin{array}{l}0.0376 \\
(0.0093,0.0659)\end{array}$ & $\begin{array}{l}0.1373 \\
(0.1082,0.1664)\end{array}$ & Robust (+) \\
\hline $\begin{array}{l}\text { Finance, insurance, and real } \\
\text { estate }\end{array}$ & $\begin{array}{l}0.0886 \\
(0.0696,0.1075)\end{array}$ & $\begin{array}{l}0.1811 \\
(0.1636,0.1986)\end{array}$ & Robust (+) \\
\hline Educational services & $\begin{array}{l}-0.0673 \\
(-0.0775,-0.0571)\end{array}$ & $\begin{array}{l}0.0147 \\
(0.0089,0.0206)\end{array}$ & Fragile \\
\hline
\end{tabular}

95 percent confidence intervals are contained under point estimates in parentheses. 